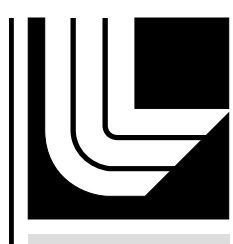

LA W REN CE LIVERMORE N A TIO NAL LABORATORY

SMALL-SCALE SAFETY TEST REPORT FOR BUTYL NITRATE

P. C. Hsu, J. G. Reynolds

April 8, 2013 
This document was prepared as an account of work sponsored by an agency of the United States government. Neither the United States government nor Lawrence Livermore National Security, LLC, nor any of their employees makes any warranty, expressed or implied, or assumes any legal liability or responsibility for the accuracy, completeness, or usefulness of any information, apparatus, product, or process disclosed, or represents that its use would not infringe privately owned rights. Reference herein to any specific commercial product, process, or service by trade name, trademark, manufacturer, or otherwise does not necessarily constitute or imply its endorsement, recommendation, or favoring by the United States government or Lawrence Livermore National Security, LLC. The views and opinions of authors expressed herein do not necessarily state or reflect those of the United States government or Lawrence Livermore National Security, LLC, and shall not be used for advertising or product endorsement purposes.

This work performed under the auspices of the U.S. Department of Energy by Lawrence Livermore National Laboratory under Contract DE-AC52-07NA27344. 


\title{
Small-scale Safety Test Report for Butyl Nitrate
}

\author{
Peter C. Hsu and John G. Reynolds \\ 925-422-0317,hsu7@Ilnl.gov \\ Lawrence Livermore National Laboratory \\ P.O. Box 808, L-282 \\ 7000 East Avenue, Livermore, CA 94551
}

February 21, 2013

\section{LLNL-TR-}

This work is performed under the auspices of the U.S. Department of Energy by Lawrence Livermore National Laboratory under Contract DE-AC52-07NA27344. 
From: Peter C. Hsu

Title: Small-scale safety test summary report-Butyl Nitrate

L-282, P.O. Box 808

(925) 422-0317 telephone

(925) 424-3281 fax

Email:hsu7@llnl.gov

Date: February 21, 2013

Distribution: Project file, John Reynolds, Peter Hsu

This report summarizes results of small-scale safety testing (drop hammer, friction and spark) and DSC analysis performed on Butyl Nitrate $(\mathrm{BN})$. Results showed that $\mathrm{BN}$ is not sensitive to impact, friction and ESD spark. Also listed in the tables below are FEFO, PETN, RDX and HMX for comparison. Impact sensitivity and friction sensitivity of BN are similar to those of TATB. BN showed some spark sensitivity but still is 5 times less-spark sensitivity than PETN when the resistance of the discharge circuit was set at zero Ohm. In summary, BN is less sensitive than some commonly used high explosives, PETN, HMX, and RDX. Weight loss measurement was made at ambient temperature when the sample bottle was kept open in order to determine whether each sample droplet would maintain its constant weight for testing. Result showed that $\mathrm{BN}$ is very volatile, losing $25 \%$ weight in a 24 -hour period. Test sample would need to be in closed containers until use. DSC analysis was performed with Setaram Instrument and results showed that the peak temperature at $219.4 \mathrm{C}$ but thermal decomposition started at around $151 \mathrm{C}$. Since BN has a low flash point $(50 \mathrm{C})$, further thermal sensitivity testing with other methods (e.g. ODTX) is recommended to test for its threshold thermal ignition temperature, time to thermal explosion at elevated temperature and thermal explosion violence [1].

\section{Impact Test Result Summary for BN}

\begin{tabular}{|c|c|c|c|c|c|c|}
\hline Sample \# & Test Date & Temp., F & $\begin{array}{c}\text { Relative } \\
\text { Humidity } \\
\text { RH, \% }\end{array}$ & $\begin{array}{c}\text { Height for } 50 \% \\
\text { Reaction }\left(\mathrm{DH}_{50}\right), \mathrm{cm}\end{array}$ & $\begin{array}{c}\text { Standard } \\
\text { Deviation }(\sigma), \\
\log \text { unit }\end{array}$ & Note \\
\hline $\begin{array}{c}\text { PCH-XIII- } \\
113 \\
\end{array}$ & $02 / 04 / 13$ & 74 & 15 & $>177$ & N/A & Bare anvil \\
\hline $\begin{array}{c}\text { FEFO } \\
\text { (liquid) }\end{array}$ & $01 / 25 / 13$ & 75 & 30 & 29.7 & 0.035 & Bare anvil \\
\hline $\begin{array}{l}\text { TMETN } \\
\text { (liquid) }\end{array}$ & & & & 15 & & Bare anvil \\
\hline PETN & & & & 15 & & $\begin{array}{l}120 \text { grit sand } \\
\text { paper }\end{array}$ \\
\hline HMX & & & . & 32 & & $\begin{array}{l}120 \text { grit sand } \\
\text { paper }\end{array}$ \\
\hline RDX & & & & 35 & & $\begin{array}{l}120 \text { grit sand } \\
\text { paper }\end{array}$ \\
\hline
\end{tabular}


BAM Friction Test Result Summary for BN

\begin{tabular}{|c|c|c|c|c|c|c|c|}
\hline $\begin{array}{c}\text { Sample } \\
\#\end{array}$ & Test Date & Temp., F & $\begin{array}{c}\text { Relative } \\
\text { Humidity, } \\
\text { RH, \% }\end{array}$ & $\begin{array}{c}\text { Friction } \\
\text { Reaction } \\
\text { (TIL) } \\
0 / 10 @\end{array}$ & $\begin{array}{c}\text { Friction } \\
\text { Reaction } \\
1 / 10 @\end{array}$ & $\begin{array}{c}\text { Load for } \\
50 \% * \\
\text { Reaction } \\
\left(\mathrm{F}_{50}\right), \mathrm{kg}\end{array}$ & $\begin{array}{c}\text { Standard } \\
\text { Deviation ( } \sigma), \\
\text { log unit }\end{array}$ \\
\hline $\begin{array}{c}\text { PCH- } \\
\text { XIIl-113 }\end{array}$ & $02 / 04 / 13$ & 75 & 16 & $36.0 \mathrm{~kg}$ & $>36.0 \mathrm{~kg}$ & $>36.0$ & NA \\
\hline PETN & & & & $\begin{array}{c}1 / 10 @ 6.4 \\
\mathrm{~kg}\end{array}$ & $\begin{array}{c}1 / 10 @ \\
6.4 \mathrm{~kg}\end{array}$ & & \\
\hline HMX & & & & & $1 / 10 @$ & & \\
& & & & & $11.6 \mathrm{~kg}$ & & \\
\hline RDX & & & & & & & \\
\hline
\end{tabular}

Static Spark Test Result Summary for BN

\begin{tabular}{|c|c|c|c|c|}
\hline Sample \# & Test Date & Temp., F & $\begin{array}{c}\text { Relative } \\
\text { Humidity RH, } \\
\%\end{array}$ & Spark Reaction \\
\hline $\begin{array}{l}\text { PCH- } \\
\text { XIII-113 }\end{array}$ & $02 / 03 / 13$ & 73 & 13 & $\begin{array}{c}0 / 10 @ 1.0 \mathrm{~J} @ 510 \\
\text { Ohms resistance; } \\
2 / 2 @ 0.25 \mathrm{~J} \text { at } 0 \\
\text { Ohms } \\
0 / 10 @ 0.15 \mathrm{~J} \text { at } 0 \\
\text { Ohms, } \\
\text { TIL = 0.15 J }\end{array}$ \\
\hline PETN & & & & $\begin{array}{c}0 / 10 @ 1.0 \mathrm{~J} @ 510 \\
\text { Ohms; TIL }=0.031 \mathrm{~J} \\
\text { at } 0 \text { Ohms }\end{array}$ \\
\hline RDX & & & & $\begin{array}{c}0 / 10 @ 1.0 \mathrm{~J} @ 510 \\
\text { Ohms; TIL }=0.038 \mathrm{~J} \\
\text { at } 0 \text { Ohms }\end{array}$ \\
\hline HMX & & & & $\begin{array}{c}0 / 10 @ 1.0 \mathrm{~J} @ 510 \\
\text { Ohms; TIL }=0.063 \mathrm{~J} \\
\text { at } 0 \text { Ohms }\end{array}$ \\
\hline
\end{tabular}

DSC Test Result Summary for BN

\begin{tabular}{|c|c|c|c|c|}
\hline $\begin{array}{c}\text { Sample } \\
\#\end{array}$ & Test Date & $\begin{array}{c}\text { DSC Onset/Peak } \\
\text { Temperatures, }{ }^{\circ} \mathrm{C}, \\
(\Delta \mathrm{H}, \mathrm{J} / \mathrm{g})\end{array}$ & $\begin{array}{c}\text { Thermal } \\
\text { decomposition } \\
\text { process }\end{array}$ & Note \\
\hline $\begin{array}{c}\text { PCH- } \\
\text { XIII- } \\
113\end{array}$ & $02 / 06 / 13$ & $\begin{array}{c}198.7 / 219.4(16) ; \\
\text { exotherm, } \\
3081 \mathrm{~J} / \mathrm{g}\end{array}$ & $\begin{array}{c}\text { Started at } 151.3 \mathrm{C} \\
\text { and ended at 338.3 C }\end{array}$ & Setaram DSC \\
\hline
\end{tabular}


Before SSST testing started, we performed weight loss study for butyl nitrate. Without sample container cap on, BN lost weight very quickly, at the rate of $25 \%$ per day. Results are shown in appendix 2 . All samples were thus kept in the container with cap on until use.

\section{Appendix 1: SSST equipment description}

Appendix 2: Weight loss study result

Appendix 3: SSST data sheets 


\section{Appendix 1: Small-scale Safety Test Capability at LLNL}

Small-scale sensitivity testing was done to determine material response to various stimuli including impact, friction, static spark and thermal. NMR was also used to analyze for the presence of reaction products if any chemical reaction would occur during the aging process. The SSST tests, briefly described below, provide parameters for determining safe handling practices.

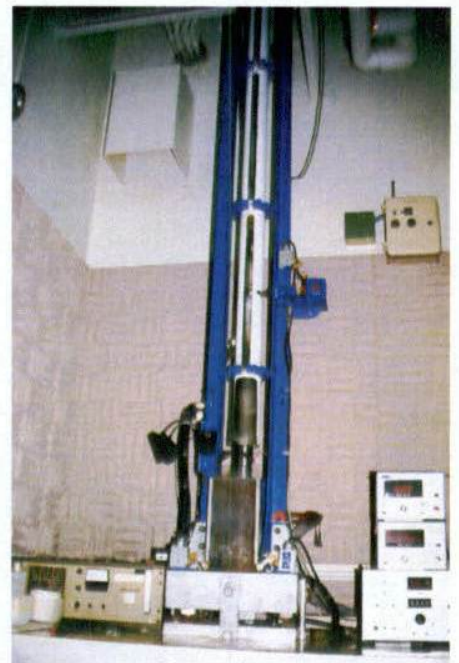

Figure 1. Drop Hammer at LLNL

\section{Drop Hammer (impact sensitivity)}

ERL Type 12 drop hammer equipment at LLNL, shown in Figure 1, was used to determine the impact sensitivity [1]. The equipment includes a 2.5-kg drop weight, a striker (upper anvil, $2.5 \mathrm{~kg}$ for solid samples and $1.0 \mathrm{~kg}$ for liquid samples), a bottom anvil, a microphone sensor, and a peakmeter. For each drop, a sample (35 mg for solids or 35 microliter for liquids) is placed on the bottom anvil surface and impacted by the drop weight from different heights. Signs of reactions upon impact are observed and recorded. These signs may include noises, flashes or sparks, smoke, pressure, gas emissions, temperature rise due to exothermic reaction, color change of the sample, and changes to the anvil surface (noted by inspection). For solid samples, a "GO" was defined as a microphone sensor (for noise detection) response of $\geq 1.3 \mathrm{~V}$ as measured by a peakmeter. The higher the $\mathrm{DH}_{50}$ values, the lower the impact sensitivity. The method used to calculate $\mathrm{DH}_{50}$ values is the "up and down" or Bruceton method [2,3]. PETN and RDX have impact sensitivities of 15 and $22 \mathrm{~cm}$, respectively (powder samples), as measured at LLNL on this apparatus. TATB has impact sensitivity more than $177 \mathrm{~cm}$, which is the maximum drop height on the LLNL instrument. For liquid samples, a "GO" was determined by the noise levels as measured by the peakmeter, appearance of flashes, temperature rise of the anvil, and visual inspection of the anvil surface. For reference, liquid explosives TMETN and FEFO have impact sensitivities of 14 and $32 \mathrm{~cm}$, respectively.

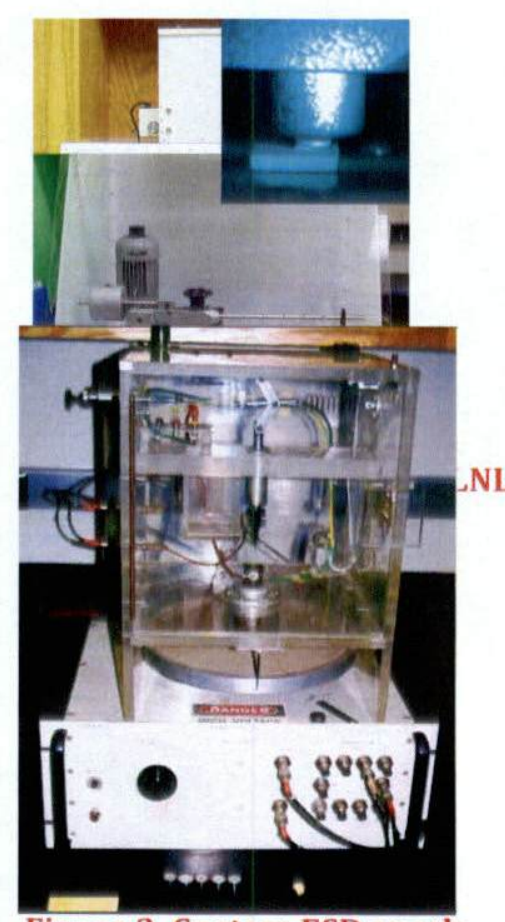

Figure 3. Custom ESD spark

\section{Frictional Sensitivity}

A BAM friction sensitivity test machine, as shown in Figure 2, was used to determine the frictional sensitivity [4]. The system uses a fixed porcelain pin and a movable porcelain plate that executes a reciprocating motion. A weight affixed to a torsion arm allows for a variation in applied force between $0.5 \mathrm{~kg}$ to $36.0 \mathrm{~kg}$. The relative measure of the frictional sensitivity of a material is based upon the smallest load $(\mathrm{kg})$ at which reaction occurs for a 1-in-10 series of attempts. The lower the load values, the higher the frictional sensitivity. PETN has a frictional sensitivity of $6.4 \mathrm{~kg}$.

\section{Spark Sensitivity}

The static spark machine at LLNL is used to evaluate the electrostatic discharge hazards (from human electrostatic discharge (ESD)) associated with the handling of explosives [5]. The machine was custom-built 
almost 30 years ago and consists of a capacitor bank (up to $20,000 \mathrm{pF}$ ), a voltage meter, and a discharge circuit, as shown in Figure 3. An adjustable resistor up to $510 \mathrm{ohms}$ (chosen to simulate the electrical resistance of the human body) is wired to the discharge circuit. A 5-mg sample is placed in a Teflon washer sealed to a steel disc and covered with a Mylar tape. High static voltage (up to $10 \mathrm{kv}$ ) is applied and discharged to the sample. Evidence of reaction is judged from the condition of Mylar tape, evolution of smoke, and color change of the sample. Voltage, capacitance, and resistance can be adjusted to achieve the desired static energy. The results obtained are expressed as a zero-in-10 or onein-ten at a specific voltage and joules. One reaction in ten trials at $\leq 0.25$ joules is considered sparksensitive. Primary explosives show reaction at $\leq 0.1$ joule.

New ABL spark test equipment, as shown in Figure 4, was procured in 2010. The system is more powerful than the existing custom built systems and is capable of discharging static energy up to $38 \mathrm{~J}$ and down to $10 \mathrm{~mJ}$. Figure 4 shows the new spark tester. The resistance in the discharge circuit can be set at 3 levels $(0 \mathrm{ohms}, 50$ ohms, or 510 ohms). The new spark tester provides greater flexibility for testing different explosives. A gas detector is connected to the new spark tester to monitor the gas emission $\left(\mathrm{CO}_{2}, \mathrm{CO}\right.$, and $\left.\mathrm{NO}_{x}\right)$ from the testing. When a spark reaction occurs, sudden increases in the

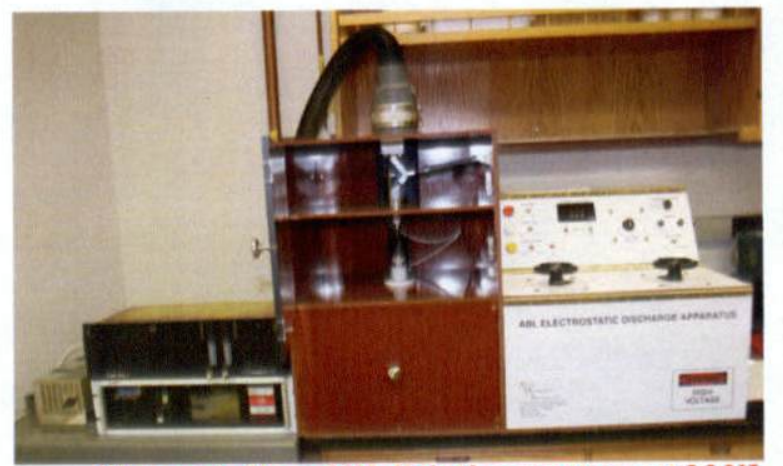

Figure 4. New ABL Friction system at LLNL concentrations of $\mathrm{CO}_{2}, \mathrm{CO}$, and $\mathrm{NO}_{x}$ are seen if molecules of test sample consist of organic carbon and organic nitrogen (e.g. TNT). The gas detector provides the operator a good tool to judge a spark reaction.

\section{Thermal (DSC) Sensitivity}
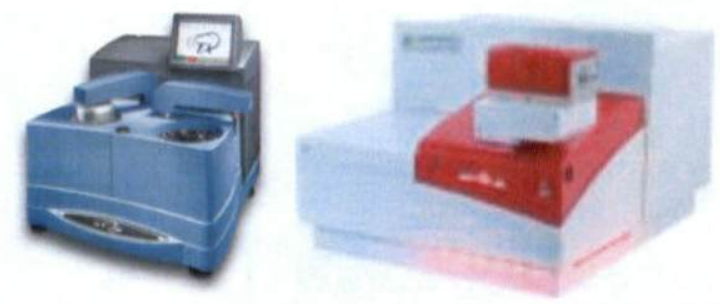

Figure 5. TA DSC and Setaram DSC at LLNL

Thermal testing was performed by differential scanning calorimetry (DSC). The standard system at LLNL is the TA Instrument Q 2920. For volatile liquid samples, the Setaram Sensys DSC is used with a sealed sample holder, which minimizes endothermic features due to volatilization. Figure 5 shows these systems. For the standard configuration, a small amount of sample, usually less than $1 \mathrm{mg}$, is placed in the sample holder and the sample is heated at a constant heating rate of $10^{\circ} \mathrm{C} / \mathrm{min}$. The heat flow is monitored in and out of the sample and presented as a function of temperature. The usual expression of results is temperature of maximum evolution $\left(\mathrm{T}_{\max }\right)$ associated with an exothermic heat flow $\left(\Delta \mathrm{H}_{\mathrm{exo}}\right)$ and a temperature of minimum evolution $\left(\mathrm{T}_{\min }\right)$ associated with an endothermic heat flow $\left(\Delta \mathrm{H}_{\text {endo }}\right)$. An exothermic event is usually associated with an energetic release (indicating a possible energetic material) and an endothermic event is usually associated with a phase change (such as a melt).

of 14 and $32 \mathrm{~cm}$, respectively.

\section{REFERENCES}

1. Hsu, P. C., "LLNL ODTX System for Thermal Safety Determination of Energetic Materials," LLNL-BR-411732, 2009. 
2. Simpson, L. R. and Foltz, M.F., "LLNL Small-Scale Drop-Hammer Impact Sensitivity Test," UCRL-ID-I19665, 1995.

3. Dixon, W.J. and Massey, F.J., "Introduction to Statistical Analysis," 2nd ed., McGraw-Hill, New York, pp 318-327, 1957.

4. Dixon, W.J., "The Up and Down Method for Small Samples," J. Am. Statistical Assoc., 60, pp 967-978, 1965.

5. Simpson, L.R. and Foltz, M.F., "LLNL Small-Scale Friction Sensitivity (BAM) Test," UCRL-ID-124563, 1996.

6. Simpson, L.R. and Foltz, M.F., "LLNL Small-Scale Static Spark Machine: Static Spark Sensitivity Test," UCRLID-135525, 1999. 
Appendix 2 : weig.ht Loss Study

\begin{tabular}{|c|c|c|c|c|c|c|c|}
\hline & Weigh & Ooss study for buty Iitt & 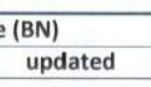 & $\begin{array}{l}\mathrm{PCH}, \mathrm{Jan} 23,2013 \\
28-\operatorname{lan}-13\end{array}$ & por & & \\
\hline $\begin{array}{l}\text { W. of EN container with cap } \\
\text { Wt. of BG contaniner w/o cap }\end{array}$ & & $\begin{array}{l}19.56437 \\
144.49914\end{array}$ & $\begin{array}{l}\text { grams } \\
\text { grams }\end{array}$ & & & & \\
\hline \multirow[b]{2}{*}{ Time } & & & With Cap & & & w/o cap & \\
\hline & $\begin{array}{l}\text { Ime unartion, } \\
\text { hours }\end{array}$ & $\begin{array}{l}\text { Total wh, contaner, } \\
\text { BN, cap, } \mathrm{g}\end{array}$ & BN, net, $\mathbf{g}$ & BN wt loss, \% & $\begin{array}{l}\text { ootal wt, } \\
\text { containe, BN, }\end{array}$ & $\mathrm{BN}$, net, $\mathrm{g}$ & BN wt loss, \% \\
\hline $\begin{array}{l}\text { 1/23/2013, 10:15 AM } \\
1 / 223 / 1313: 20\end{array}$ & & 24.4140 & 4.57766 & 0.0000 & 166.5137 & 2.0546 & 0.0000 \\
\hline \multirow{2}{*}{ 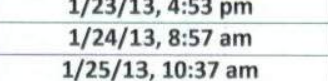 } & & $\begin{array}{l}24.1407 \\
24.1410\end{array}$ & $\begin{array}{l}4.5674 \\
4.5766 \\
-15\end{array}$ & $\begin{array}{l}0.0002 \\
0.002\end{array}$ & $\begin{array}{l}16.4249 \\
16.3412\end{array}$ & $\begin{array}{l}1.9658 \\
1.8821\end{array}$ & $\begin{array}{l}4_{3.3216} \\
8.3960\end{array}$ \\
\hline & 22.5 & $\begin{array}{l}24.1402 \\
241400\end{array}$ & 4.5759 & $\begin{array}{l}0.0170 \\
0.0170 \\
0\end{array}$ & $\begin{array}{l}15.9798 \\
15798\end{array}$ & $\begin{array}{l}1.50207 \\
1.5208\end{array}$ & $\begin{array}{l}25.9861 \\
25.981 \\
2\end{array}$ \\
\hline \multirow[t]{3}{*}{ 1/28/13, 10:23 am } & $\begin{array}{l}4.40 \\
120\end{array}$ & $\begin{array}{l}24.1400 \\
24.1368\end{array}$ & $\begin{array}{l}4.5566 \\
4.5724 \\
-104\end{array}$ & $\begin{array}{l}0.0229 \\
0.0922 \\
-10\end{array}$ & $\begin{array}{l}15.4257 \\
14.4678\end{array}$ & $\begin{array}{l}0.9666 \\
0.0086\end{array}$ & $\begin{array}{l}529.9444 \\
995804\end{array}$ \\
\hline & & & & & & & \\
\hline & & \multicolumn{3}{|c|}{ Time, hours } & & & \\
\hline \multirow[t]{2}{*}{$100=$} & & \multirow{2}{*}{\multicolumn{3}{|c|}{$\begin{array}{l}\text { No cap, wt loss was } 99.6 \% \\
\text { after } 120 \text { hours }\end{array}$}} & 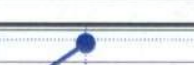 & & \\
\hline & & & & & & & \\
\hline \multicolumn{8}{|l|}{80} \\
\hline \multicolumn{8}{|l|}{$2 \quad 1$} \\
\hline \multirow{2}{*}{\multicolumn{8}{|c|}{ 恶 $60=$}} \\
\hline \multirow{2}{*}{\multicolumn{8}{|c|}{ 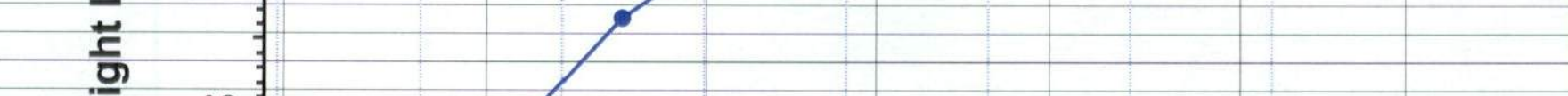 }} \\
\hline & & & & & & & \\
\hline \multicolumn{8}{|l|}{$\overline{\bar{\omega}}$} \\
\hline \\
\hline \multirow{2}{*}{\multicolumn{8}{|c|}{$\begin{array}{l}\text { With Cap, wt loss } 0.1 \% \\
\text { after } 120 \text { hours }\end{array}$}} \\
\hline & & & & & & & \\
\hline \multirow{3}{*}{1} & & & & & & & \\
\hline & 20 & 40 & & 100 & 120 & 140 & \\
\hline & & \multicolumn{3}{|c|}{ Time, hours } & & & \\
\hline
\end{tabular}




\section{Appendix 3 : S.SS T Datasheets for Butyl Nitrate DROP HAMMER TEST REPORT}

Operator:

Reviewed and approved by:

Date of Test:

Name of Explosive:

Identification Number:

Composition:

Requester:

Project No:

Task No:

Sample Description:

Test Type:

Temperature:

Humidity:

Book Reference:

Number of X's

Number of O's

$+/-0.5$

Least Height for X's or O's

LOG of Least Height

LOG of Interval

\# of Events at Least Height
Gary Hust

Peter Hsu

$2 / 4 / 13$

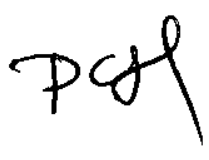

Butyl Nitrate liquid

PCH-XIII-113

P. Hsu

38086

Task 1

35 microliter Liquid

$12 \mathrm{~A}$

$74^{\circ} \mathrm{F}$

$15 \%$

25-36

0

15

0.5

177.4

2.2490

0.05

NO GO GO

15

$0 \quad 177.4$

REMARKS: none

Dh $_{50}$ CALCULATION

$\operatorname{Sum}\left(N_{i}{ }^{*} i\right)$

Sum of Events for Calculation

LOG of $\mathrm{Dh}_{50}$

$\mathrm{Dh}_{50}$

$>177 \mathrm{~cm}$

STANDARD DEVIATION CALCULATION $\operatorname{Sum}\left(\mathrm{N}_{\mathrm{i}}{ }^{*} \mathrm{i}^{2}\right)$

STANDARD DEVIATION

N/A

MAXIMUM $\mathrm{Dh}_{50}$

N/A

MINIMUM $\mathrm{Dh}_{50}$

N/A 
Operator: Gary Hust

Reviewed and approved by: Peter Hsu Pcff

Requester: P. Hsu

Project No: 38086

Task No: Task 1

Material: Butyl Nitrate

Identification Number: $\mathrm{PCH}-\mathrm{XIII-113}$

Composition:

Temperature: $75^{\circ} \mathrm{F}$

Relative Humidity: $16 \%$

Test Results: $0 / 10 @ 36.0$ kg

Remarks: 
ABL Spark Denstivity Iest Keport
Operator: Gary Hust
Material: Butyl Nitrate
ID/lot \#:

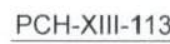
$\begin{array}{ll}\begin{array}{l}\text { Requester: } \\ \text { Date: }\end{array} & \text { P. Hsu } \\ \text { Resistance ohms } & \underline{2 / 4 / 13} \\ : & \frac{0}{13}\end{array}$
Project \#/Task \# 38086 / Task 1
Temp (deg F): 73

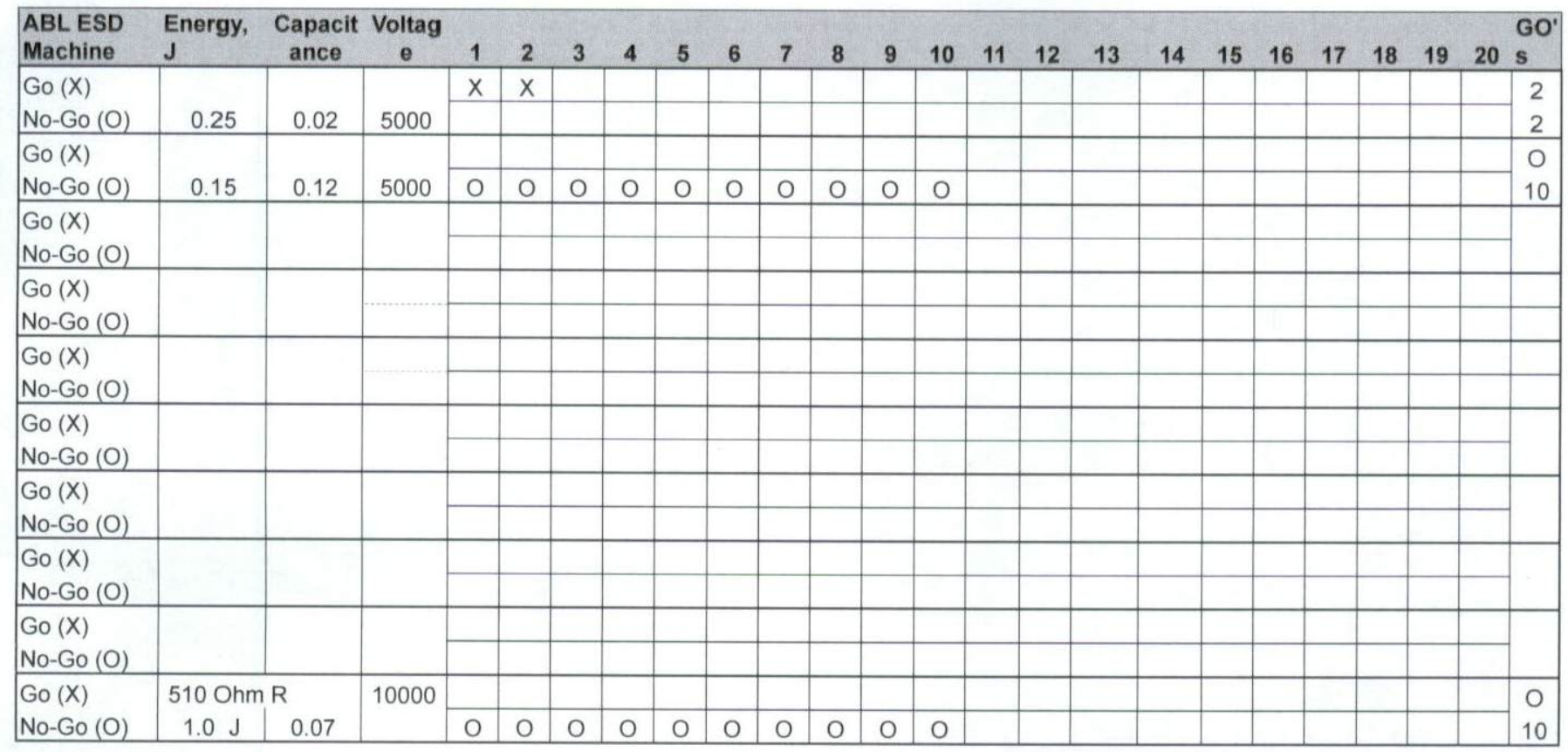

\section{TIL $=\quad 0.15 \quad \mathrm{~J}$ at 0 Ohms 0/10@1.0 J at 510 Ohms

$$
\mathrm{X}=\text { reaction }
$$

Gas detection mode (circle): $\mathrm{CO}, \mathrm{CO} 2, \mathrm{NO} \times$ Observe the electric arc shape for organic explosives

Use Tape? No

Yes for inorganic explosives

No for organic explosives
(Gas Analyzer) typically increases by more than 50 ppm for most

organic explosives when reaction

occurs.

\section{Reference}

materials TIL

PETN $0.031 \mathrm{~J}$

RDX $0.038 \mathrm{~J}$

HMX $0.063 \mathrm{~J}$ 


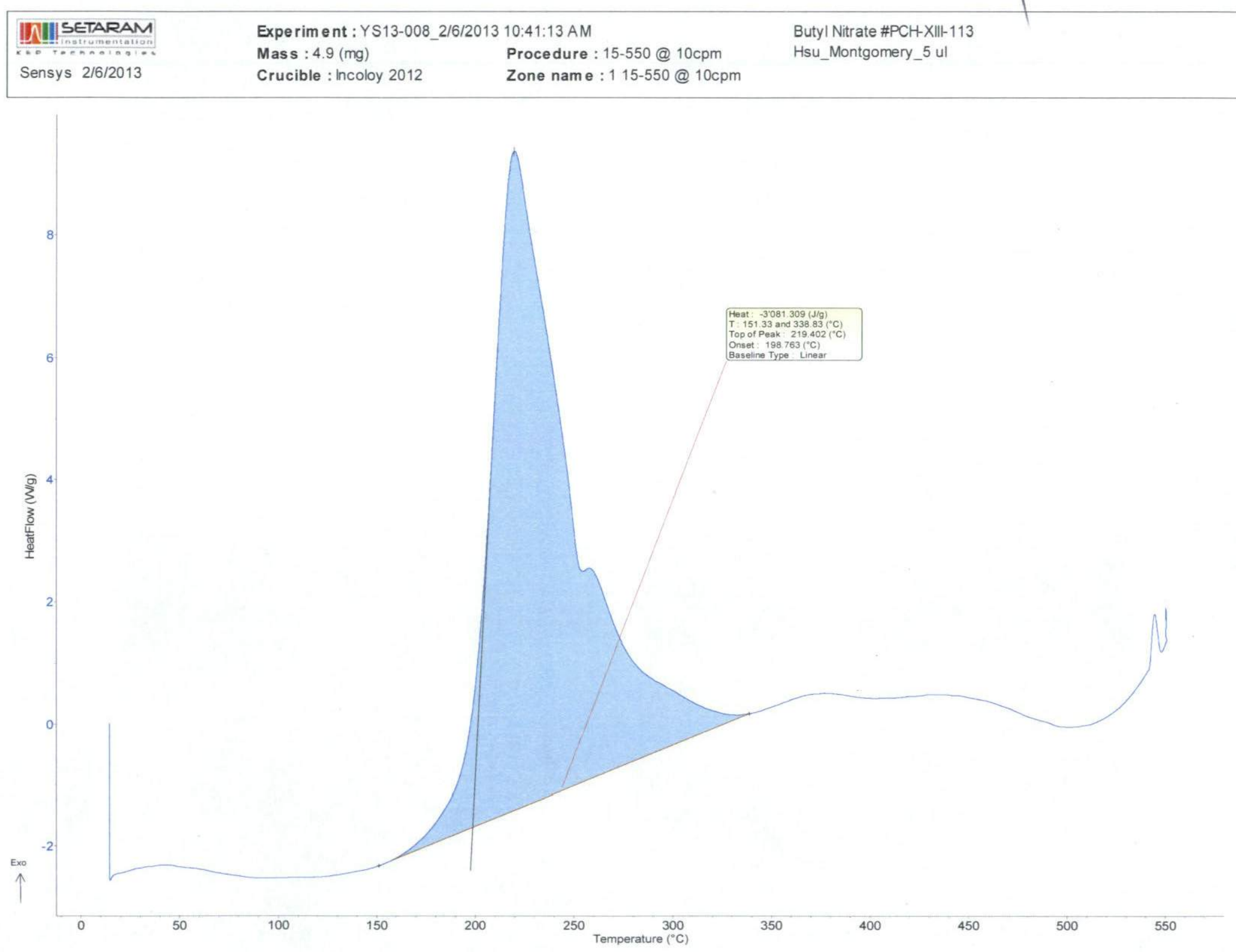


Operator:

Reviewed and approved by:

Date of Test:

Name of Explosive:

Identification Number:

Composition:

Requester:

Project No:

Task No:

Sample Description:

Test Type:

Temperature:

Humidity:

Book Reference:

Number of $X ' s$

Number of O's

$+/-0.5$

Least Height for X's or O's

LOG of Least Height

LOG of Interval

\# of Events at Least Height

\# of Events at Next Height

\# of Events at Next Height

\# of Events at Next Height

\# of Events at Next Height

\# of Events at Next Height
Gary Hust

Peter Hsu

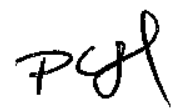

$1 / 25 / 13$

FEFO

B-153

FEFO

Liquid standard

P. Hsu

35 micro-liters

Liquid

$75^{\circ} \mathrm{F}$

$30 \%$

25-34

10

5

0.5

25

1.3979

0.05

$1 \quad 25.0$

$3 \quad 28.1$

$1 \quad 31.5$

$0 \quad 35.3$

$0 \quad 39.6$

$0 \quad 44.5$

Dh $_{50}$ CALCULATION

REMARKS:

Sum $\left(N_{i}^{*} i\right)$

5

Sum of Events for Calculation

5

LOG of $\mathrm{Dh}_{50}$

1.4729

$\mathrm{Dh}_{50}$

$29.7 \mathrm{~cm}$

STANDARD DEVIATION CALCULATION

$\operatorname{Sum}\left(N_{i} * i^{2}\right)$

7

STANDARD DEVIATION

0.035

MAXIMUM $\mathrm{Dh}_{\mathbf{5 0}}$

$32.2 \mathrm{~cm}$

MINIMUM Dh 50

$-2.3$

$27.4 \mathrm{~cm}$ 